Ann. Biol. anim. Bioch. Biophys., 1978, 18 (6), 1413-1426.

\title{
Effect of hypothalamic deafferentation on LH and sexual behaviour in ovariectomized ewe under hormonally induced oestrous cycle
}

\author{
par J. C. THIERY, J. PELLETIER, J. P. SIGNORET \\ with the technical assistance of Colette LAVENET, P. ORGEUR, G. VENIER \\ Station de Physiologie de la Reproduction, I.N.R.A., \\ Nouzilly, 37380 Monnaie, France.
}

Summary. We have investigated the effect of surgical isolation of the mediobasal hypothalamus of ovariectomized ewes on LH secretion (basal level, rhythmicity and cestradiolinduced surge) and progesterone-œstradiol induced sexual receptivity. The disruption of the posterior inputs (just anterior to the mamillary bodies) was without any endocrine or behavioural consequence. The bilateral disruption of antero-dorsal inputs resulted in the suppression of OB-induced LH surge and damping of the mean basal level. This effect was observed both shortly after surgery, and 3 months later ( 2 artificial cycles in each case). The pulsatility of LH basal secretion remained evident regardless the drastic damping of the level. Such results suggest that antero-dorsal inputs, coming from preoptic-suprachiasmatic areas are required both for the positive feed-back of oestrogens on LH secretion, and for the maintenance of the basal level of secretion. The persistence of the pulsatile pattern of secretion suggests that the mechanism involved could be located in the medio-basal area. In 8 cases the normal sexual receptivity induced by progesterone-oestrogen treatment was maintained despite elimination of the LH surge. In the 5 others, both sexual behaviour and LH surge were suppressed. In such cases the sections extended more dorsally, suggesting the importance of the dorsal part of the anterior mediobasal hypothalamus for the organisation of sexual behaviour.

As first described by Halász and Pupp (1965), deafferentation of the hypothalamus has proved to be a highly valuable method of investigating the role of the brain in the regulation of endocrine functions of numerous species. In the rat, surgical disconnection of hypothalamic areas demonstrated that the mediobasal hypothalamus $(\mathrm{MBH})$ regulates tonic secretions of gonadotrophins whereas the anterior hypothalamus-preoptic area is responsible for cyclic LH release which triggers ovulation.

In the monkey, the work of Krey et al. (1975) tends to suggest that the two main functions regulating the secretion of gonadotrophins, i. e. tonic release and preovulafory surge, may be localized in the MBH. However Norman et al. (1976) using the same techniques, suggested a possible role for a more anterior part of the brain.

In the sheep, the progesterone-oestrogen treatment which induces sexual receptivity in the ovariectomized female (Robinson, 1954) has been reported to result in a 
« preovulatory » fype surge of LH (Pelletier and Signoret, 1969). In these circumstances, sexual interactions hasten LH release (Signoret, 1975) as is the case in the intact female (Lindsay ef al., 1975). These observations suggest the possibility of an interference with the sexual behaviour mechanisms and those controlling LH secretion.

The role of the hypothalamus in the ewe has been investigated so far mainly by lesion or stimulation techniques. Lesions of the anterior mediobasal hypothalamus eliminate oestrous behaviour without interfering with ovarian cyclicity whereas both are abolished following destruction in the central part of the mediobasal area (Clegg et al., 1958 ; Radford, 1967 ; Przekop and Domanski, 1970). On the other hand, stimulation of the anterior or posterior part of the $\mathrm{MBH}$ (just posterior to the optic chiasma or just anterior to the mamillary bodies respectively) can trigger ovulation. Furthermore, oestrogen implants in this area can induce sexual behaviour in ovariectomized females (Signoref, 1970).

The use of deafferentation techniques in sheep has been reported by Jackson et al. $(1976,1978)$, both reports indicate a possible role of the anterior hypothalamus in the regulation of the preovulatory $\mathrm{LH}$ surge.

A preliminary experiment (Thiery ef al., 1977) supported the results obtained by Jackson ef al. (1976), and suggested that the consequences of hypothalamic deafferentation could be extended to the control of FSH and prolactin secretion and of sexual behaviour. This study did not rule out possible changes due to season or to unspecific effects of surgery. Accordingly a more extensive investigation of the effects of hypothalamic deafferentation was undertaken with a comparatively large number of animals, involving not only the observation of the $\mathrm{LH}$ surge but also of the basal $\mathrm{LH}$ levels, the pulsatile pattern of LH secretion and sexual behaviour.

FSH and prolactin secretion were also determined and will be reported elsewhere. The results have been obtained in anterior deafferentated, sham-operated and control groups and also in posterior deafferentated subjects, thus taking into account the possible role of the posterior input.

\section{Material and methods.}

- Animals and experimental groups. - Thirty lle-de-France ewe were used. They were ovariectomized several weeks before the beginning of the study and maintained under artificial oestrous cycles up to that date. The experiment lasted from December 1976 to April 1977.

Animals were allocated at random in 5 groups according to the type of surgical treatment :

- 6 animals were unoperated (Control group),

- 14 animals underwent a deafferentation anterior to MBH (ADA group),

- 5 animals underwent a deafferentation posterior to the MBH (PDA group),

- 5 animals were sham-operated.

- Surgical procedure. - The subjects were prepared for stereotaxic approach as described by Richard (1967) for this species; they were maintained under halothane anesthesia (4 to 5 p. 100 in air). A $7 \mathrm{~mm}$ craniectomy was performed on each side of the midline between planes A20 and A40, according to Richard's stereotaxic atlas (1969). 
Three $\mathrm{mm}$ of the dura mater was excised on each side of the longitudinal sinus, which was then sectioned after double ligature.

The knife was lowered in the midline of the brain with the blade pointing anteriorly, under $X$-ray control, until contact with the floor of the brain, as assessed by feel. The cut was made within the range $1 \mathrm{~mm}$ anterior to $1 \mathrm{~mm}$ posterior to the anterior clinoid process, i. e. plane 28.5 to 30.5 of the stereotaxic atlas (15 animals, ADA). For the 5 PDA animals, the knife was lowered to the same depth, but $4.5 \mathrm{~mm}$ posterior to plane 29, i. e. posterior edge of the MBH. The « Halasz's knife » was made of stainless steel needle and modified as follows. Starting from the tip the needle was opened along its longitudinal section for $9 \mathrm{~mm}$ by careful grinding. The opened section was then flattened and sharpened.

The final shape of the blade was obtained by doubly twisting $4 \mathrm{~mm}$ horizontally, $4 \mathrm{~mm}$ vertically. The knife was supported by a guide allowing both rotation and vertical movements inside the guide.

The $\mathrm{MBH}$ disconnection was obtained by a $180^{\circ}$ rotation of the knife $\left(90^{\circ}\right.$ on each side) with slight vertical movements $(1 \mathrm{~mm}$ ). These movements (punching) were performed in order to prevent escape of brain tissue due to a possible deformation of the wall of the third ventricule, described in the monkey by Krey ef al. (1975).

The sam operated animals underwent complete preparation including introduction of the knife and contact with the floor of the brain, but the knife was not rotated.

After the operation, the cerebral cortex was covered with gelatin sponge after local application of antibiotics. Dental cement was then put in the hole of the cranium, retained by stainless steel screws fixed in the bone. Finally, the skin was stitched.

The animals were given antibiotics for 3 days and were kept in a warm room for 7 days.

They were subsequently returned to the sheep barn and were kept under routine conditions. Although in good condition, an increase in water intake and in urination in the flock containing operated animals was noted, suggesting a possible diabetes insipidus in some of the operated females. Two females (one posterior deafferentated and one anterior deafferentated) died within 3 days of surgery.

- Hormonal treatments. - Artificial estrous cycles were induced in females using an adaptation of Robinson's (1954) treatment, i. e. $25 \mathrm{mg}$ of progesterone in olive oil/day for 5 days, $10 \mathrm{mg}$ of progesterone in olive oil on day 6 followed 48 hrs later by an injection of $50 \mu \mathrm{g}$ of oestradiol benzoate (OB) in olive oil, all intramuscularly injected. The animals underwent 3 sequences of 2 successive 14-day artificial cycles, the first sequence before surgery, the second 15 to 45 days postoperatory (STC : short-term cycle), and the last one 85 to 115 days after operation (LTC: long-term cycle).

- Blood sampling schedule and experimental planning. — In all instances blood was collected from the jugular vein and the blood sampling pattern was varied according to the type of secretion studied. In the first cycle of a sequence, blood was sampled by venepuncture at 3 hourly infervals from the time of the OB injection up to $42 \mathrm{hrs}$ later Sampling from 0 to $15 \mathrm{hrs}$ following OB was necessary for better appreciation of FSH and prolactin secretion (not part of this study). In the second cycles, blood was first sampled at the time of $O B$ injection and again from 15 up to 42 hrs later at 3 hourly intervals. 
In order to study the pattern of basal LH secretion, serial blood samples were taken every 10 min for 4 hrs (via an indwelling cannula) on day 30 after the last $O B$ injection of the short term cycles. Furthermore the sensitivity of the pituitary gonadotropin cells was tested one week later. Hence, $100 \mu \mathrm{g}$ of LHRH in phosphate buffer was injected intravenously. Animals were bled at successive intervals before and after injection of the LH-RH (- $60 \mathrm{~min},-45,-30,-15,0,+15,+30,+45 \mathrm{~min}$, etc... up to $8 \mathrm{hrs})$. $\mathrm{LH}$ values were measured by radioimmunoassay according to Pelletier et al. (1968). All samples from study of the cycles were assayed with $0.4 \mathrm{ng} / \mathrm{ml}$ sensitivity. Serial samples from the study of basal pulsatile secretion were assayed with $0.15 \mathrm{ng} / \mathrm{ml}$ sensitivity in order to elucidate as clearly as possible the post-operative rhythm in experimentals (see results). Animals of the anterior posterior and sham-operated groups were killed at the end of the experiment for histological study of the brain.

- Histology. - After slaughter the brains were removed, fixed in 10 p. 100 buffered formaldehyde and embedded in paraffin wax. The traces were observed in serial frontal sections of $15 \mu \mathrm{m}$ thickness, stained with the Klüver-Barrera technique. These traces were reported on a reconstructed sagittal projection adapted from Richard's stereotaxic atlas (fig. 1). However, the exact shape of the suprachiasmatic nuclei was slighly modified with report to Diepen's (1941) description and that of Welento ef al. (1969). Furthermore, a description of median eminence - pars fuberalis (not included in the original atlas) was added. Careful examination of these structures was necessary for a clearer understanding and interpretation of the results.

- Sexual behaviour. - The sexual receptivity was assayed by presenting females individually for $2 \times 5^{\prime}$ periods to sexually active rams 24 and $36 \mathrm{hrs}$ after $O B$ injection (Thiery and Signoret, 1978).

\section{Results.}

1. Control. - In all animals but one, OB injection induced a decrease in LH level due to negative feedback effect; this was followed by a large surge 18 to $24 \mathrm{hrs}$ later (positive feedback effect) and sexual receptivity. The same effect was observed in the pre-experimental cycle of the operated animals. No change related to season could be detected in LH values between control, short and long term cycles (fig. 2).

Interruption of the steroid treatment for 30 days revealed a pulsatile pattern of $\mathrm{LH}$ secretion. Although individual pulses were less regular in some animals than in freshly ovariectomized ewes, the rhythm of occurence of pulses (45 to $60 \mathrm{~min}$ ) (Butler ef al., 1972) was still evident (see fig. 3).

2. Sham-operated and posterior deafferentated groups. - In both groups the operation did not affect any of the endocrine or behavioral variables examined. The general

FIG. 1. - Histological localization of the deafferentation in frontal section. (Arrow indicates cut). A : Posterior deafferentation. B : Anferior unilateral deafferentation in ewe no. 17. C-D : Bilateral anterior deafferentation in ewes no. 10 and 4.

Note proliferation of fibroblastic tissue in $C$ and $D$ (left) and complete separation of the hypothalamus in D (right). 
aspect of the sections (bilateral) indicated that the knife was accurately used in the sheep brain (fig. 1).

3. Anterior deafferentated group (ADA). - In 11 out of 13 animals no LH preovulatory type surge could be detected following progesterone/oestrogen treatment. Furthermore, the initial $\mathrm{LH}$ level measured at the time of $\mathrm{OB}$ injection was markedly reduced in each case. In the two other cases, a small (about $20 \mathrm{ng} / \mathrm{ml}$ ) but distinct LH surge could be detected (fig. 2).

Normal sexual behaviour was observed in 8 females after surgery, but it was completely abolished in the 5 others.

In all 13 cases, the variation in LH values between ST and LT sequences of two cycles was very small. However, (i) 2 animals showned, during LT cycles, a slight increase in $\mathrm{LH}$ levels (about $5 \mathrm{ng} / \mathrm{ml}$ at the time when before surgery, a peak could normally be observed) while no responses were detected during ST cycles, (ii) 9 showed small increases $(5.39 \pm 0.71 \mathrm{ng} / \mathrm{ml})$ in both ST and LT cycles, (iii) two others shown no responses at all.

Therefore, the results are given with no special reference to short or long-term cycles since there was no consistent variation in the comparison of these cycles. All LH values presented below are expressed as the mean \pm standard error of the mean ; for the 4 individual cycles (two ST and two LT), or two preoperative control cycles.

Hisfology and relationships with hormonal data. - We observed a bilateral section in 10 out at 13 animals which varied widely in size (cut width ranged from 3 to $7 \mathrm{~mm}$ ), although in some animals the cuts were not strictly bilateral at the extremities. However, this difference in laterality did not induce any consistent change in hormonal values. The anterior localization of the cut appeared to be the only important anatomical feature, and thus only differences in antero-posterior localization were thought to be relevant.

Of the 10 animals, 2 (" arcuate $»)$ had been sectioned at the level of the arcuate nuclei, 3 («post-suprachiasmatic ») between the suprachiasmatic and the arcuate nuclei, and 5 (" suprachiasmatic ») through the posterior part of the suprachismatic nuclei (fig. 4). All but one had lost the ability to discharge LH after OB injection. The remaining animal did not show an $\mathrm{LH}$ surge before surgery although a slight increase was evident between 18 to $24 \mathrm{hrs}$ in 3 out of the 4 postoperative cycles.

The initial LH level (measured at OB injection time) fell dramatically, i. e. mean : $1.75 \pm 0.43$ versus $9.24 \pm 1.36 \mathrm{ng} / \mathrm{ml}$ before surgery. No statistically significant variations could be deduced with respect to antero-posterior location of the cut despite the fact that $\mathrm{LH}$ levels were affected in all animals. However, the mean initial LH level in the 5 most anteriorly deafferentated animals $(2.69 \pm 0.74 \mathrm{ng} / \mathrm{ml})$ seemed to be less depressed than the initial LH level in the 3 post suprachiasmatic ones $(0.96 \pm 0.54 \mathrm{ng} / \mathrm{ml})$.

Pulsatile pattern of $L H$ secretion. - Here again, as describe for the initial LH level observed at the time of $O B$ injection, the basal level is clearly lower in the 10 animals with bilateral sections than in the control group.

Independently, however, all these animals exhibited pulses of secretion. Some of them showed very regular pulses of LH while the others showed a less regular, althought clear, rhythm (fig. 3). 
ng /ml plasma LH
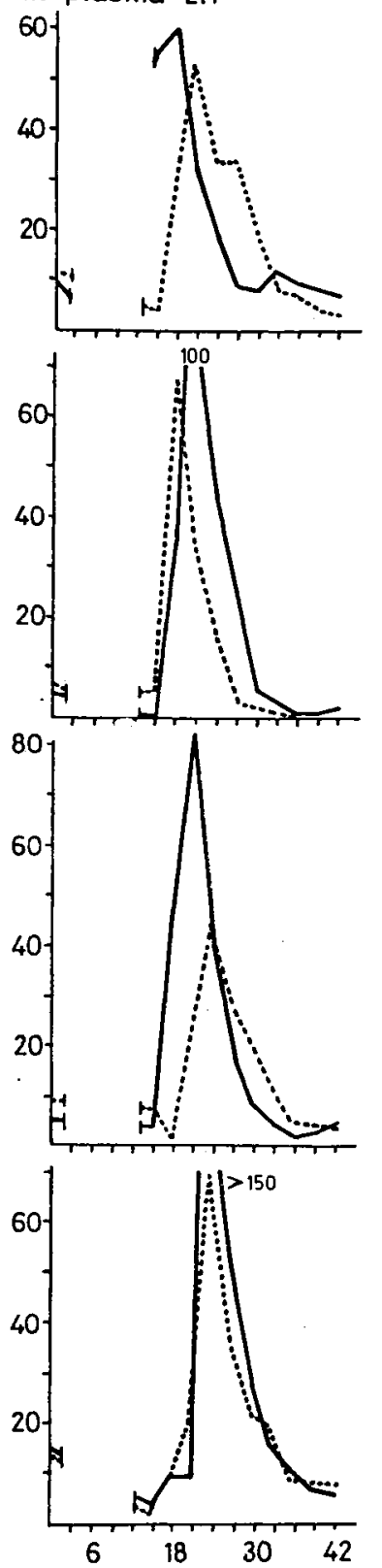

CONTROL EWES

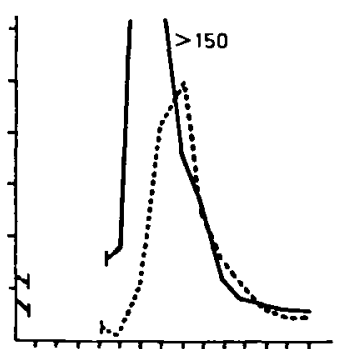

A.D.A EWES
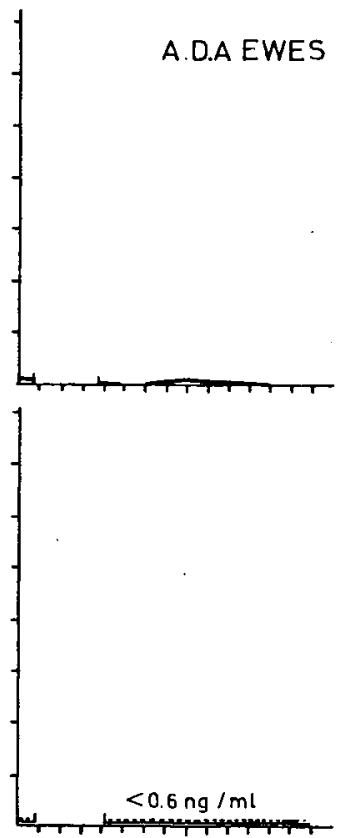

UNILATERAL A.D.A EWES

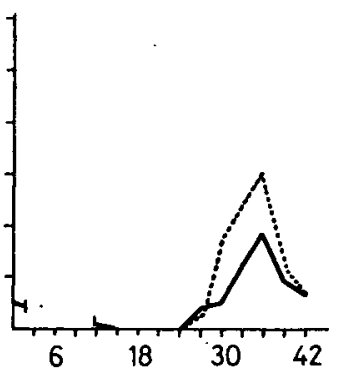

8
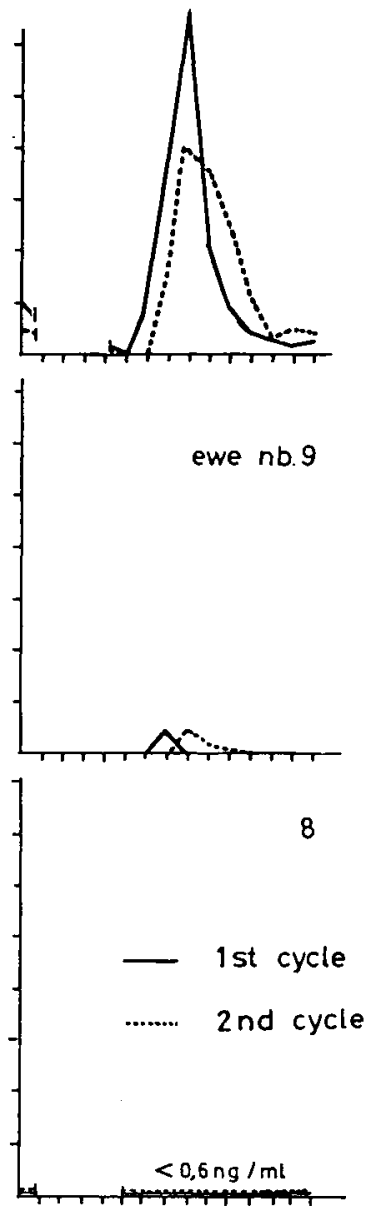

ewe nb. 9

15

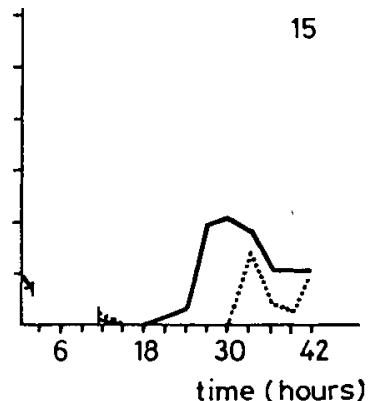

FIG. 2. - Evolution of $\mathrm{LH}$ response affer astradiol benzoate injection (0 time) in 1 control ewe, 2 anterior deafferentated ewes (ADA ewes no. 9 and 8) and 1 unilateral anterior deafferentated ewe (no. 15). Two successive artificial cycles were used in each case. "Control cycles 》 : before surgery ; "Short-term cycles » : 15 to 45 days after surgery ; "Long-term cycles »: 85 to 115 days after surgery. 
$\mathrm{ng} / \mathrm{ml}$ plasma LH

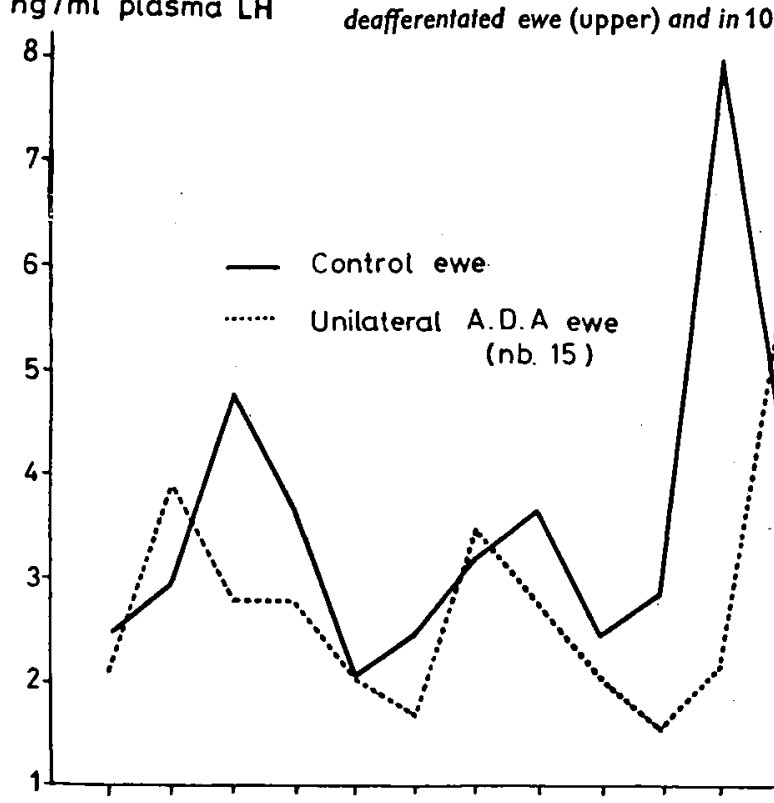

A.D.A EWES
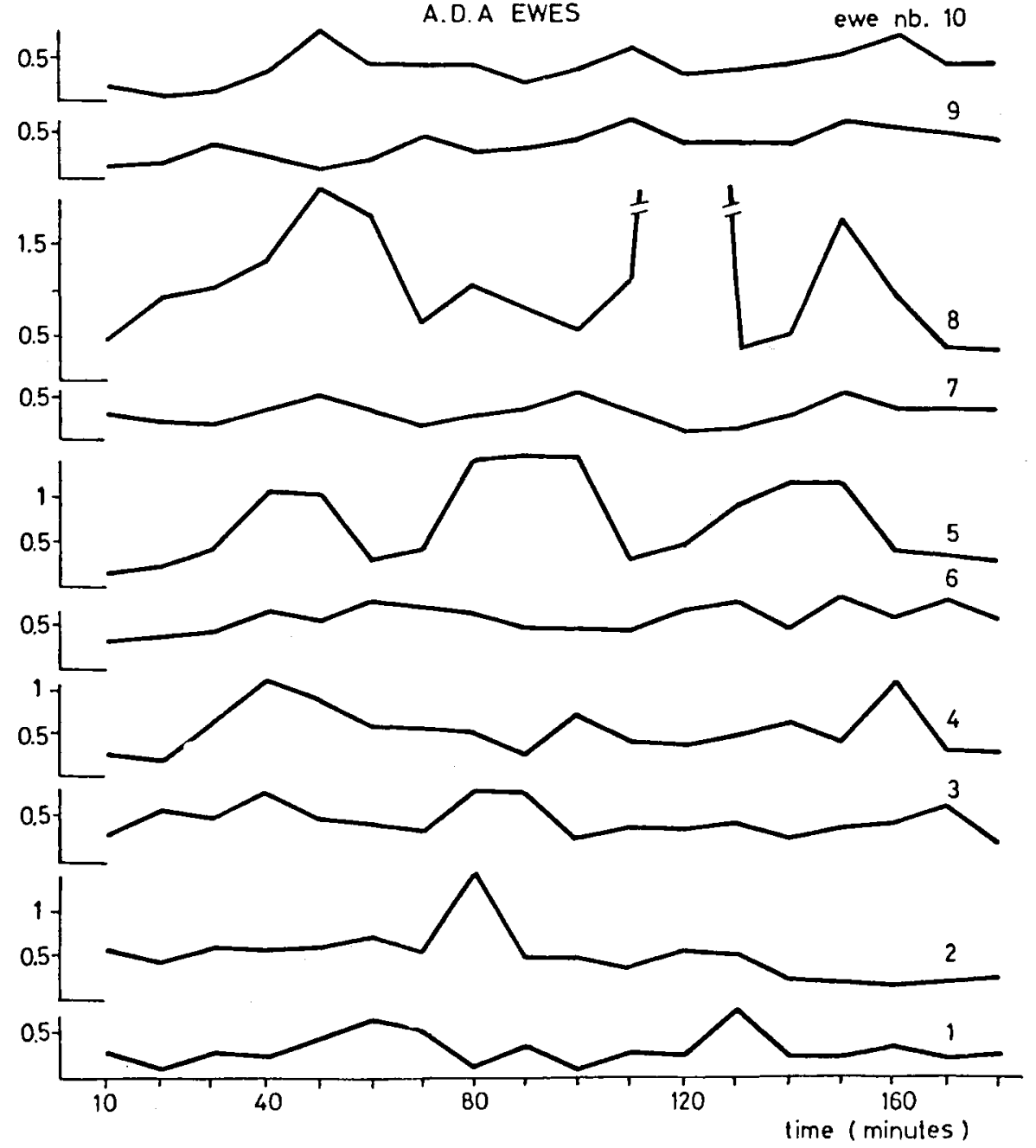
In 3 of the 13 animals, the deafferentation was predominantly or exclusively unilateral : In one the section was localized at the arcuate level and included a part of median eminence. In another the section was posterior to the suprachiasmatic nucleus but a lesion appeared at the level of the median eminence. Both showed suppression of the OB induced LH surge and damping of the initial basal level. In the third the LH surge was damped (about $30 \mathrm{ng} / \mathrm{ml}$ ) and considerably delayed when compared with the pre-operative cycle (fig. 2). The section was located in the posterior part of the suprachiasmatic nucleus.

All the 3 subjects exhibited a normal rhythmicity of basal LH secretion.

Pituitary responsiveness to $\mathrm{LHRH}$ injection. - The response was present in all the 13 animals. Six of them (4 bilaterally and 2 unilaterally deafferentated) showed res-

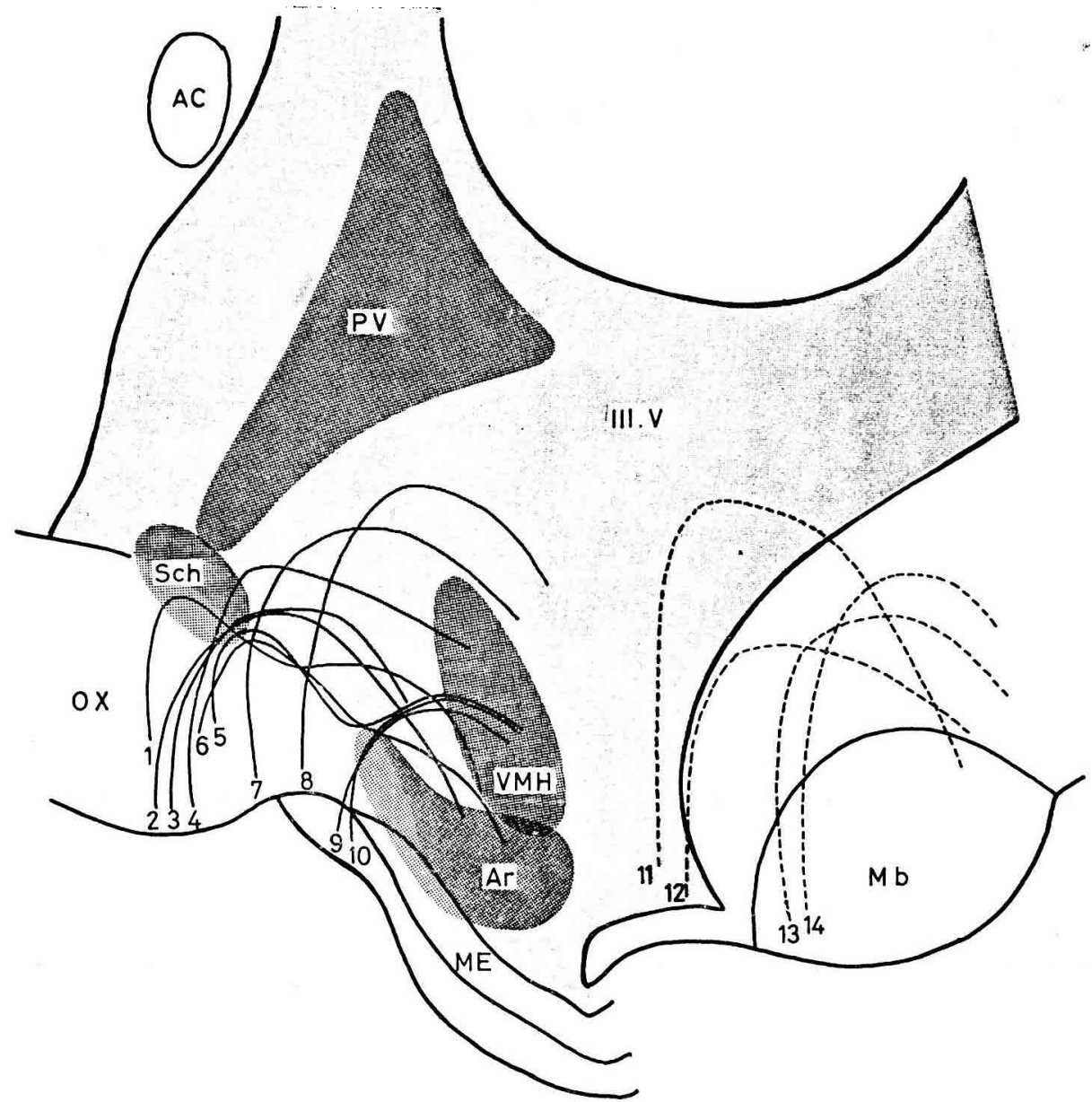

FIG. 4. - Schematic sagitfal drawing of the localization of the cuts in the 10 anterior bilateral deafferentated ewes (from 1 to 10) and the 4 posterior deafferentiated ewes (from 11 to 14). AC = Anterior Commissure $; \mathrm{Ar}=$ Arcuate nucleus $; \mathrm{ME}=$ Median eminence $; \mathrm{Mb}=$ Mamillary bodies ; OX : Optic chiasma ; PV = Paraventricular nucleus ; Sch : Suprachiasmatic nucleus ; VMH : Ventromedial nucleus; III $V=$ Third ventricule. 
ponses; the maximum value after LH-RH injection ranged from 33 to $126 \mathrm{ng} / \mathrm{ml}$. These values were similar to the control group which had a range of 47 to $101 \mathrm{ng} / \mathrm{ml}$. The remaining 7 animals had clear but reduced responses. In this group, 3 had a cut which affected the arcuate nucleus at the level of the median eminence ( 2 bilaterally and 1 unilaterally deafferentated) (fig. 5).

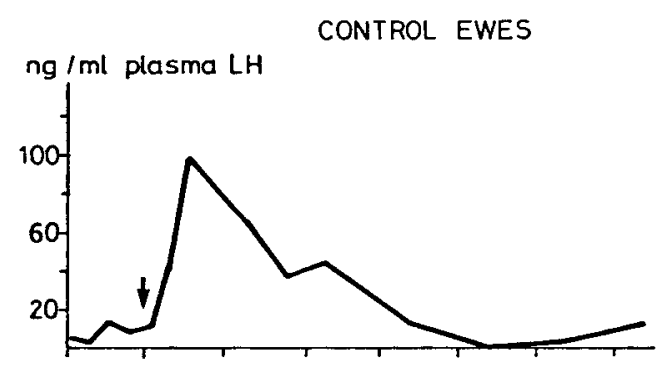

A.D.A EWES
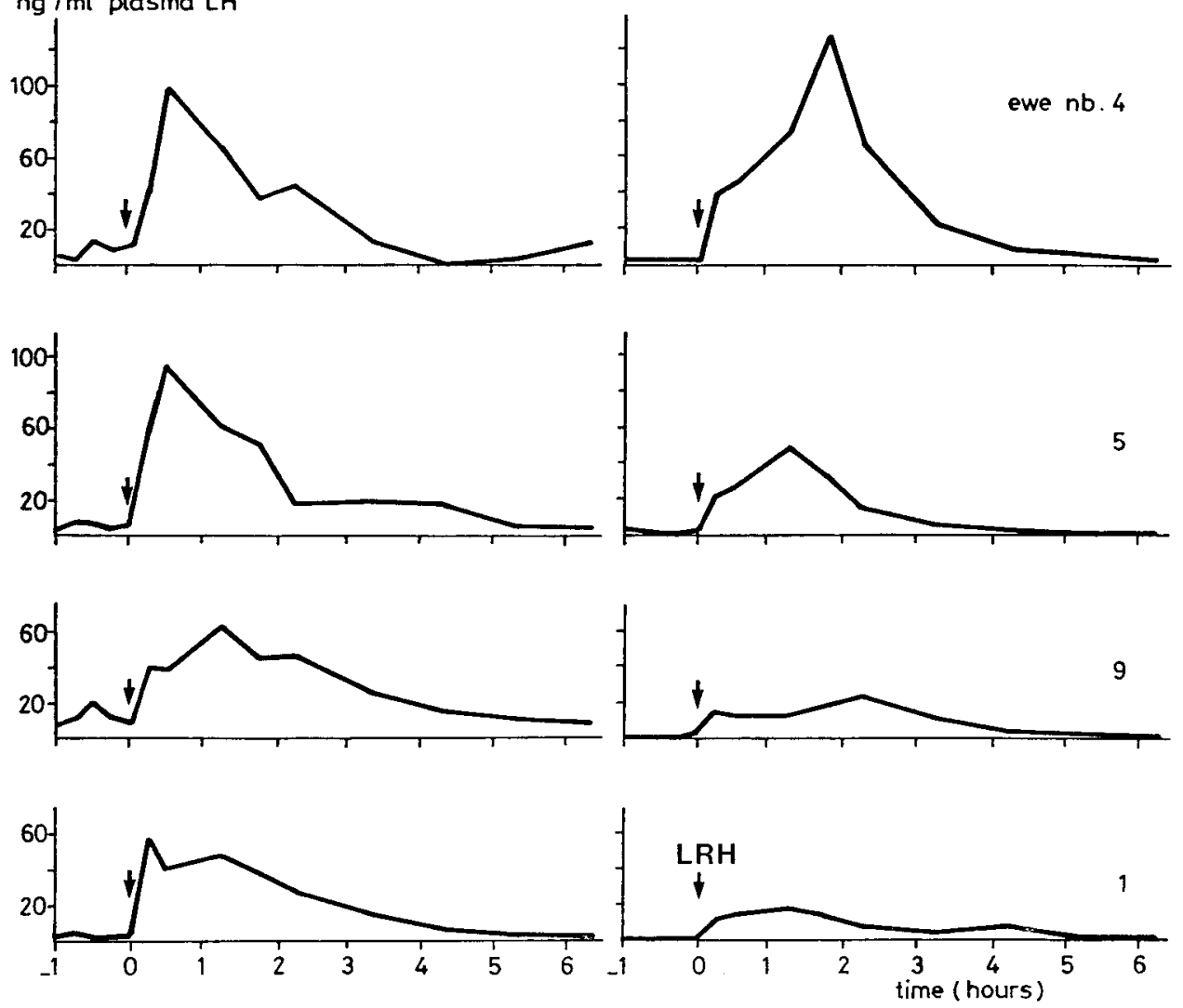

FIG. 5. - Evolution of $L H$ response after $100 \mu \mathrm{g}$ LRH injection (arrow). Left $=$ control ; right $=$ after anterior deafferentation : ewes no. 4 and 5 showed normal responses while no. 9 and 1 showed reduced althought clear responses.

Histology and behavioural effects. - Eight bilaterally deafferentated subjects retained normal sexual behaviour ( $31 / 32$ cases, with the exception of one cycle of one ewe). This was associated with the absence of the normal «preovulatory »-type $\mathrm{LH}$ surge. The sections were all localized ventrally (fig. 6).

In the five remaining females both sexual behaviour and the LH peak were eliminated. In this case, the sections were localized more dorsally (3 bilateral and 2 predominantly unilateral). 


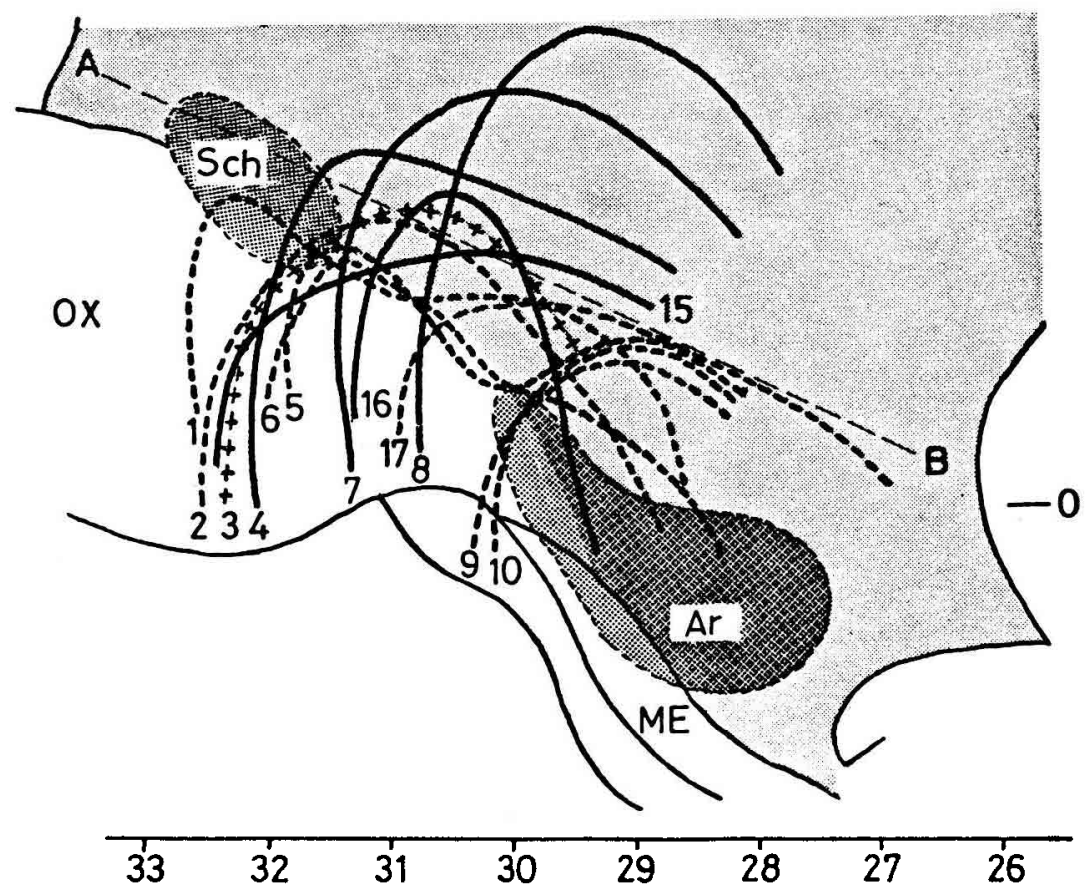

FIG. 6. - Effect of the anterior deafferentation on sexual behaviour. Interrupted line : Ewes having presented normal sexual behaviour after deafferentation. Solid line : elimination of sexual response. Crossed line : the ewe no. 3 was not sexually receptive during the first treatment post surgery but recovered a normal sexual sexual behaviour later. All the cuts interfering with the sexual receptivity are extending dorsally to $A B$ line.

\section{Discussion.}

The results show a drastic damping of the OB-induced LH surge, associated with the persistance of normal sexual behaviour, following bilateral deaffentation frontally to the $\mathrm{MBH}$.

These effects cannot be interpreted as a non-specific consequence of the operation, since neither sham-operated nor posterior deafferentated females exhibited any differences from the unoperated controls. The absence of any recovery between short term and long term cycles indicate also that this effect is not due to a femporary trauma.

Such changes in $\mathrm{LH}$ secretion cannot be due to a pituitary necrosis following stalk damages (Bryant et al., 1971) since LH responses to LH-RH injection, although affected in some cases, especially those where the arcuate nucleus was involved in the cut, clearly indicated a good responsiveness of the pituitary gland (the value was 4-12 times higher than the eventual residual increase evoked by OB injection). Similar results have been recently reported by Jackson et al. (1978). Thus an essential role of anterior and/or dorsal inputs in the regulation of this mechanism is indicated. The ineffectiveness of the lesion at this level reported by Przekop and Domanski (1970) suggests that the inputs pass more centrally and ventrally and remain undamaged while in our 
work the cuts which reach the floor of the hypothalamus result in a more marked suppression of the inputs. This is also in complete agreement with the results of Jackson ef al. (1978). Thus, in the ewe, as in female rat since the pioneer work of Halász and Pupp (1965), inputs coming from areas anterior to the $\mathrm{MBH}$ are required for maintenance of the positive feed-back of œstrogens on LH surge. This is also similar to the situation of the Rhesus Monkey where Norman et al. (1976) demonstrated the effectiveness of the anterior hypothalamus-preoptic areas lesions in blocking the oestrogensinduced $\mathrm{LH}$ response.

However, in most cases LH increased slightly at the normal time of OB-induced surge, and although affected, basal levels remained detectable. This suggests that most inputs running near the sagittal midline of the brain were suppressed by the cut while a few more lateral and/or dorsal connections remained undamaged. Such a situation has been described in the rat. Setáló ef al. (1976) found that frontal deafferentation only depressed the $\mathrm{LH}-\mathrm{RH}$ content of the $\mathrm{MBH}$ while total deafferentation diminished it completely. An alternative could be the presence of oestradiol sensitive LH-RH cells in the mediobasal area.

In ovariectomized ewes, one of the characteristics of basal LH secretion is the rhythmic occurence of pulses (40 to $70 / \mathrm{min}$, Butler et al., 1972). In our study, rhythmicity is still evident after surgery, regardless of the LH level. This suggests that the mechanism responsible for the pulsatile pattern of secretion is located in mediobasal areas, as suggested in rat by Blake and Sawyer (1974) or that the residual pulsatile secretion could be due to a possible lateral or dorsal inputs not disrupted by the cut.

The damping of the level could be due to the elimination of a number of LRH cells anterior to the cut, as well as the elimination of excitatory inputs coming from that zone. It is intersting to note that recent results (Hoffman et al., 1978) shows in male sheep two populations of LRH cells, one in septo-preoptic areas and the other in mediobasal hypothalamus, i. e. one anterior and one posterior to the cut in our experiments. Such results suggest that, in the ewe, the mechanisms responsible for basal LH secretions (rhythm and level) could imply both mediobasal and more anterior structures.

The effects of deafferentation on behavioural reactions suggest that the nervous pathways controlling the organization of sexual receptivity run more dorsally than those involved in the regulation of LH secretion. The elimination of sexual receptivity after the sections were placed more dorsally stresses the importance of this area in the control of sexual behaviour. Lesions in this zone may result in a disruption of female receptivity without interfering with the control of gonadotropin secretion, as ovarian cyclicity has been shown to be maintained in animals with such lesions (Clegg et al., 1958 ; Przekop and Domanski, 1970).

These results indicate that there is an independance at the hypothalamic level in the oestrogen-induced activation of pathways involved in the organization of sexual behaviour and those involved in the neuronal control of LH secretion. Such an independance in the pathways does not allow any positive or negative conclusion to be drawn on the unitary or multiplicity of their neuronal origins, nor on the possible intervention of LH-RH as suggested in rats (Moss and Foreman, 1976). 
Acknowledgements. - The authors wish to acknowledge the courtesy of Dr. Jackson who communicated the preprint of his results and the assistance of J. William who prepared the English translation of the manuscript. The work was supported by A.T.P. INSERM-46-77-78, Contrat $n^{0} 7$ « Hormones neuropeptides et réactions comportementales normales et pathologiques $\gg$.

Résumé. Nous avons réalisé des déafférentations de l'hypothalamus médiobasal chez la brebis ovariectomisée. Les effets ont été examinés sur le rythme et le niveau de sécrétion basale de $\mathrm{LH}$, la décharge induite par les œstrogènes ainsi que sur la réceptivité sexuelle résultant du traitement progestérone-œstrogènes. La section des afférences postérieures (en avant des corps mamillaires) est sans effet sur les paramètres endocriniens et comportementaux examinés. La section bilatérale des afférences antéro-dorsales supprime la décharge de $\mathrm{LH}$ induite par les œestrogènes et abaisse son niveau de sécrétion basale. Cet effet de l'opération est observé sans changements juste après celle-ci ou trois mois plus tard, au cours de deux cycles artificiels dans chaque cas. Le rythme de sécrétion de l'hormone subsiste malgré la chute du niveau. Ces résultats suggèrent que les afférences antéro-dorsales issues des zones préoptiques et supra-chiasmatiques sont nécessaires au maintien de la rétroaction positive des oestrogènes sur la $\mathrm{LH}$ comme au niveau de la sécrétion de celle-ci. La persistance du rythme de la sécrétion montre que le mécanisme responsable de celui-ci pourrait être localisé dans l'hypothalamus médiobasal. Dans 8 cas, la réceptivité sexuelle induife par le traitement stéroïdien a été maintenue malgré la suppression de la décharge de LH. Dans 5 autres cas, la réceptivité sexuelle et la décharge de LH ont été éliminées. Pour ces derniers, la section s'étendait plus dorsalement, ce qui suggère le rôle des zones plus dorsales de l'hypothalamus médiobasal antérieur dans l'organisation du comportement sexuel.

\section{References}

BLAKE C. A., SAWYER C. H., 1974. Effects of hypothalamic deafferentation on the pulsatile rhythm in plasma concentrations of luteinizing hormone in ovariectomized rat. Endocrinology, 94, 730-735.

BRYANT G. D., GREENWOOD F. C., KANN G., MARTINET J., DENAMUR R., 1971. Plasma prolactin in the cestrous cycle of the ewe : effects of pituitary stalk section. J. Endocr., 51, 405-406.

BUTLER W. R., MALVEN P. V., WILLETT L. B., BOLT D. J., 1972. Patterns of pituitary release and cranial output of LH and prolactin on ovariectomized ewes. Endocrinology, 91, 793-801.

CLEGG M. T., SANTALUCITO J. A., SMITH J. D., GANONG W. F., 1958. The effect of hypothalamic lesions on sexual behavior and estrous cycles in the ewe. Endocrinology, 62, 790-797.

DIEPEN R. B., 1941. The hypothalamic nuclei and their ontogenic development in ungulates (ovis aries). Diss Amsterdam, $97 \mathrm{pp}$.

HALÁSZ B., PUPP L., 1965. Hormone secretion of the anterior pituitary gland after physical interruption of all nervous pathways to the hypophysiotropic area. Endocrinology, 77, 533-562.

HOFFMAN G. E., MELNYK V., HAYES T., BENNETT-CLARKE C., FOWLER E., 1978. Immunocytology of LHRH neurons, 66-82. In : SCOTT D. E., KOZLOWSKI G. P., WEINDL A., Brain endocrine interaction, III. Karger, Basel.

JACKSON G. L., KUEHL D., ZALESKI A., 1976. Effects of anterior hypothalamic deafferentation on LH secretion in the ewe. 9th Ann. Meet. Soc. Study of Reprod., Univ. of Pens. Abst. no 27.

JACKSON G. L., KUEHL D., MCDOWELL K., ZALESKI A., 1978. Effects of hypothalamic deafferentation on secretion of luteinizing hormone in the ewe. Biol. Reprod. (in press).

KLÜVER H., BARRERA E., 1953. A method for the combined staining of cells and fibers in the central nervous system. J. Neuropathol. exp. Neurol., 12, 400-403. 
KREY L. C., BUTLER W. R., KNOBIL E., 1975. Surgical disconnection of the medial basal hypothalamus and pituitary function in the rhesus monkey. I. Gonadotropin secretion. Endocrinology, 90, 1073-1087.

LINDSAY D. R., COGNIE Y., PELLETIER J., SIGNORET J. P., 1975. Influence of the presence of rams on the timing of ovulation and discharge of $L H$ in ewes. Physiol. Behov., 15, 423-426.

MOSS R. L., FOREMAN M. M., 1976. Potentiation of lordosis behavior by intrahypothalamic infusion of synthetic luteinizing hormone. Releasing hormone. Neuroendocrinology, 20, 176-181.

NORMAN R. L., RESKO J. A., SPIES H. G., 1976. The anterior hypothalamus : how it affects gonadotropin secretion in the rhesus monkey. Endocrinology, 99, 59-71.

PELLETIER J., KANN G., DOLAIS J., ROSSELIN G., 1968. Dosage radioimmunologique de l'hormone luteinisante plasmatique chez le mouton. Mise au point de la technique de dosage. C. R. Acad. Sci. Paris, sér. D, 266, 2291-2294.

PELLETIER J., SIGNORET J. P., 1969. Contrôle de la décharge de LH dans le sang par la progestérone ef le benzoate d'œstradiol chez la brebis castrée. C. R. Acad. Sci., Paris, Sér. D, 269, 2595-2598.

PRZEKOP F., DOMANSKI E., 1970. Hypothalamic centers involved in the control of gonadotropin secretion and ovulation in sheep. Acta physiol. pol., 21, 34-49.

RADFORD H. M., 1967. Electrical stimulation of ovulation in the ewe. J. Endocr., 38, 477-478.

RICHARD P., 1967. Atlas stéréotaxique du cerveau de brebis, ed. INRA (Paris).

ROBINSON T. J., 1954. Relationships of cestrogen and progesterone in œstrous behaviour of the ewe. Nature, 173, 878.

SETALO G., VIGH S., SCHALLY A. V., ARIMURA A., FLERKO B., 1976. Immunohistological study of the origin of LH-RH containing nerve fibers of the rat hypothalamus. Brain Res., 103, 597-602.

SIGNORET J. P., 1970. Action d'implants de benzoate d'œestradiol dans l'hypothalamus sur le comportement d'œstrus chez la brebis ovariectomisée. Ann. Biol. anim. Biochim. Biophys., 10, 549-566.

SIGNORET J. P., 1975. Influence of the presence of ram on the luteining hormone surge after cestradiol benzoate injection in ovariectomized ewes. J. Endocr., 64, 589-590.

THIERY J. C., SIGNORET J. P., BLANC M., PELLETIER J., RAVAULT J. P., CARATY A., LAVENET C., ORGEUR P., POIRIER J. C., VENIER G., 1977. Effects of anterior hypothalamic deafferentation on LH, FSH, prolactin and sexual behaviour in the ovariectomized ewe. IRCS Med. Sci., $5,434$.

THIERY J. C., SIGNORET J. P., 1978. Effect of changing the teaser ewe on the sexual activity of the ram. Appl. Anim. Eth., 4, 87-90.

WELENTO J., SZTEYN S., MILART Z., 1969. Observation on the stereotaxic configuration of the hypothalamic nuclei in the sheep. Anat. Anz., 124, 1-27. 